\title{
Nondestructive Evaluation of Wood Decayed by Xylophagous Organisms
}

\author{
Michael Weiler, André L. Missio ${ }^{\mathrm{b} *}$, Darci A. Gatto ${ }^{\mathrm{b}, \mathrm{c}}$, William G. Güths ${ }^{\mathrm{d}}$ \\ ${ }^{\mathrm{a} D i v i s i o n}$ of Methods and Processes, Wood Industrial Engineering, \\ S.C.A Mobiliário Contemporâneo, CEP 95700-000, Bento Gonçalves, RS, Brazil \\ ${ }^{\mathrm{b}}$ Forest Products Laboratory, Post-graduate Program in Forest Engineering - PPGEF, \\ Center of Rural Sciences, Federal University of Santa Maria-UFSM, \\ CEP 97105-900, Santa Maria, RS, Brazil \\ ${ }^{\mathrm{c}}$ College of Wood Industrial Engineering, Federal University of Pelotas - UFPel, \\ CEP 96010-290, Pelotas, RS, Brazil \\ ${ }^{\mathrm{d}}$ Wood Industrial Engineering, Pelotas, RS, Brazil
}

Received: October 3, 2012; Revised: May 21, 2013

\begin{abstract}
The aim of this study was to investigate the effects of attack by xylophagous organisms on the physicomechanical properties of Araucaria angustifolia wood from the floor of a historic house in Pelotas, Southern Brazil using two nondestructive methods. To achieve this, samples were collected from the floor for visual assessment by photography in metric scale. All the images were exported to CAD software in order to measure the percentage of the sample's surface attack in relation to its total area. Subsequently, nondestructive tests were performed using an ultrasound with two types of transducers. Mechanical properties of the material was measured through static bending tests and these results were compared with the results of nondestructive methods. The nondestructive methods of computerized visual analysis and ultrasound were efficient for quantifying the surface attack and showed a good relationship with the results obtained in static bending tests.
\end{abstract}

Keywords: ultrasonic methods, computerized visual methods, Araucaria angustifolia, wood technology

\section{Introduction}

Wood is the most important renewable feedstock in the world but for many applications, the life cycle is limited by its natural low durability ${ }^{1}$. In general, wood-based products are exposed to several external conditions, such as mechanical wear from continuous loads, moisture changes, fungal degradation and insect attack ${ }^{2}$. Wood is an organic and biological material that suffers the action of xylophagous organisms, which are responsible for a partial or complete deterioration and reduction of service life.

Many and simple techniques are used to evaluate the degree of wood deterioration, such as visual inspection with magnifying lens and nondestructive tests (NDT) in order to complement the results ${ }^{2}$. NDT is the science for identification of the physical and mechanical properties of a material in order to make decisions without modifying the final uses ${ }^{3,4}$. The advantages of NDT's are security, low cost, versatility ${ }^{5,6}$, considerable reduction in the test time, standard laboratory equipment are not required ${ }^{7,8}$, estimation of defects in the material ${ }^{7,9,10}$ and easy transport of the equipment in comparison to destructive techniques.

The main NDT techniques are: ultrasonic wave propagation - which is divided into acoustic wave techniques (Acoustic emission - AE) and ultrasonic's waves (Acousto ultrasonic emission - AU) ${ }^{11}$-, electrical resistance, colorimetry, dielectric properties, X-ray, transverse vibration technique or resonance technique, and the stress wave method $^{12}$

*e-mail: andreluizmissio@gmail.com
AU techniques are mainly employed to illustrate the biological modifications of the wood structure, determine the elastic constants and evaluate the sawing. Techniques that use resonance frequency, ultrasound velocity and acoustic emission can evaluate the structural and functional integrity of many wood products ${ }^{13}$. AU techniques are essential to ensure the security of the structure analyzed and, consequently, a big service life through the methods of defects repair ${ }^{10}$.

The constant evolution of NDTs ${ }^{14}$ contrasts with a decrease in the use of destructive methods, which, despite achieving more accurate results, the time required for analysis, equipment cost, difficulties in the transport and the destruction of the samples thwart or even make impracticable the use of such methods.

In this context, the present study aimed to characterize the effects of attack by xylophagous organisms on the physicomechanical properties of the wood using a visual computerized analysis and ultrasonic methods.

\section{Material and Methods}

\subsection{Location and samples preparation}

Wood samples from Araucaria angustifolia specie attacked by termites were collected from a floor in a historic house located in Pelotas ( $31^{\circ} 46^{\prime} 19^{\prime \prime} \mathrm{S}$ and $52^{\circ} 20^{\prime} 34^{\prime \prime} \mathrm{W}$, $7 \mathrm{~m}$ above sea level), Southern Brazil. The material was 
macroscopically identified as described in Procedure for Wood Anatomy Study: Gymnosperms ${ }^{15}$.

Forty samples measuring $80 \mathrm{~mm} \times 20 \mathrm{~mm} \times 310 \mathrm{~mm}$ (width, length and thickness) were prepared in order to perform three ultrasonic assays (A, B and C) with flat side transducers (frequency of $50 \mathrm{kHz}$ and diameter of $5 \mathrm{~cm}$ ). Subsequently, the samples were resized to $20 \mathrm{~mm} \times 20 \mathrm{~mm}$ $\times 310 \mathrm{~mm}$ for ultrasonic assays with a dry point contact transducer, totalizing 120 samples, as illustrated in Figure 1.

The samples were then placed in a climate chamber at $20{ }^{\circ} \mathrm{C}$ and $65 \%$ relative humidity to obtain equilibrium moisture content $(\sim 12 \%)$.

\subsection{Evaluation of biological attack}

\subsubsection{Computerized visual analysis}

The computerized visual analysis was performed to evaluate the percentage of attack by xylophagous organisms in relation to the total area of the sample. Photographs in a metric scale were taken using a digital camera. All the images were exported to CAD software in order to quantify the percentage of the attack presented in each sample. To achieve this, the surface areas with attack by xylophagous organisms were demarcated (graphic plot) and the percentage of attack in relation to the total area for each sample was measured.

As observed in Table 1, the surface attack was classified into five groups in order to facilitate data visualization. Each group corresponds a percentage level of attack, in which $0 \%$ means no attack and $100 \%$ signify fully attacked.

The computerized visual analysis was performed in the resized samples, e.g., in 120 samples measuring $20 \times 20 \times 310 \mathrm{~mm}$. Thus, the subdivision of the groups

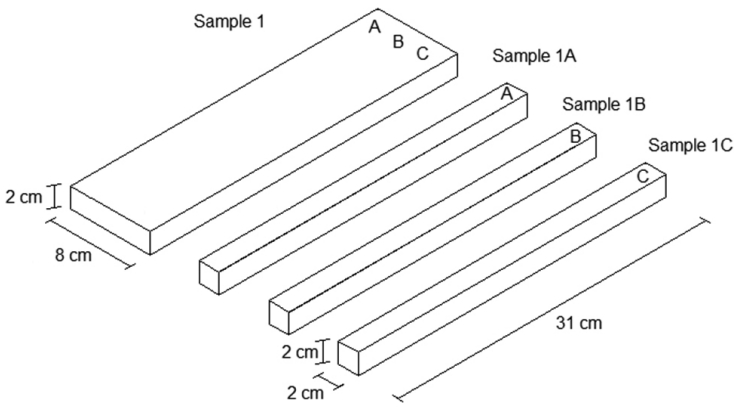

Figure 1. Scheme of wood samples preparation from the Araucaria angustifolia floor.

Table 1. Groups for the classification of samples in relation to the level of attack by xylophagous organisms.

\begin{tabular}{cc}
\hline Group & Level of attack $(\boldsymbol{\%})$ \\
\hline $\mathrm{T} 1$ & Zero \\
$\mathrm{T} 2$ & $0.01-9.99$ \\
$\mathrm{~T} 3$ & $10.00-19.99$ \\
$\mathrm{~T} 4$ & $20.00-49.99$ \\
$\mathrm{~T} 5$ & $50.00-100.00$ \\
\hline
\end{tabular}

was unbalanced with differentiated sampling number and the statistical analysis was performed with unbalanced data.

\subsection{Nondestructive evaluation}

Nondestructive tests were performed through a TICO ${ }^{\circledR}$ ultrasound (made in Switzerland) equipped with two flat side transducers $(50 \mathrm{kHz})$. Transducers remained distant from $20 \mathrm{~cm}$ in order to perform three measurements (Figure 1) for the determination of time of wave propagation.

The resized samples $(20 \mathrm{~mm} \times 20 \mathrm{~mm} \times 310 \mathrm{~mm})$ were used in nondestructive tests with dry point transducers (standard frequency of $54 \mathrm{kHz}$ ). Three measurements of time of wave propagation on the longitudinal direction and on the center of the cross section and the average value was considered. The use of two types of transducers was proposed in order to verify any disparities in the results of prediction of wood defects, which could help to indicate the best solution for any problem.

Velocity of ultrasonic wave propagation (V) in meters per second was determined based on ratio of distance (L) between the transducers and time of ultrasonic wave propagation $(\mathrm{t})$. Thus, dynamic modulus of elasticity $\left(\mathrm{E}_{\mathrm{D}}\right)$ was also determined through Equation 1.

$\mathrm{E}_{\mathrm{D}}=\mathrm{V}^{2} \cdot \mathrm{D} \cdot 10^{-6}$

In which: $\mathrm{E}_{\mathrm{D}=}$ Dynamic modulus of elasticity $(\mathrm{MPa})$; $\mathrm{V}=$ velocity of ultrasonic wave propagation $\left(\mathrm{m} \cdot \mathrm{s}^{-1}\right)$; $\mathrm{D}=$ Basic density $\left(\mathrm{kg} \cdot \mathrm{m}^{-3}\right)$.

$\mathrm{E}_{\mathrm{D}}$ measured with flat side transducers was named $\mathrm{E}_{\mathrm{Df}}$ and the variable measured with dry point transducers was named $E_{D d}$. Measurement of basic density was performed based on Brazilian Technical Standards Association - NBR $7190^{16}$.

\subsubsection{Destructive evaluation}

Static bending tests were performed using a universal testing machine with capacity of $200 \mathrm{kN}$. Tests were carried out as described by American Society for Testing and Materials - ASTM D 143-9417 and static modulus of elasticity (MOE) and modulus of rupture (MOR) were determined.

\subsection{Data analysis}

The data collected were analyzed through analysis of variance (ANOVA) and regression models were adjusted. The comparison in ANOVA was performed with F Test at $5 \%$ of probability of error. When the null hypothesis was rejected, the average values were compared with Fisher LSD (Least Significant Difference) Test at $5 \%$ of probability of error.

Heterogeneity of variance, normality and independence of residuals in the mathematical models were verified by White, Shapiro-Wilk and Durbin-Watson tests, respectively. The models were created differentiating the groups (see Table 1) and the type of transducer used. The dependent variable was MOE and the independent variables were $E_{D f}$ and $\mathrm{E}_{\mathrm{Dd}}$. The adjustment of quality of models was evaluated by the coefficient of determination $\left(\mathrm{r}^{2}\right)$, the mean absolute error (MAE), F statistic and p-value. 


\section{Results and Discussion}

\subsection{Basic density variation}

As observed in Table 2, the attack by xylophagous organisms was characterized for the variation of basic density of the samples (groups T1-T5) based on computerized analysis, i.e., analysis of percentage of surface attack.

Basic density (D) of healthy wood samples (T1) showed higher average value and was statistically different from all groups with an attack by xylophagous organisms (T2, T3, T4 and T5) (Table 2). Construction of galleries inside the wood characterizing the attack by xylophagous organisms (termites), which decrease the weight but maintain the same volume and, consequently, decrease D. Average value of group T1 was higher than found in other studies, which were $550 \mathrm{~kg} \cdot \mathrm{m}^{-3[18]}$ and $520 \mathrm{~kg} \cdot \mathrm{m}^{-3[19]}$.

The higher average value of density than those found in other aforementioned studies could be explained due to the wood samples were collected in a historic house after 70 years or more of exposure. In this period, building construction is carry out with a centennial trees (high proportion of mature wood), whereas other studies ${ }^{18,19}$ used wood from trees 19 and 50 years old, respectively.

Researchers ${ }^{20}$ studied wood degradation by ultrasonic method and reported that weight loss was proportional to the exposure time of wood samples to xylophagous organism. The authors found $42.35 \%$ of weight loss after 16 weeks of exposure, which was higher than the highest weight loss found in the present study $(21.07 \%)$.

\subsection{Ultrasonic wave propagation velocity}

The velocity of ultrasonic wave propagation (V) measured for flat side transducers did not show a defined tendency, in which only the treatment T2 was significant higher (Figure 2). The standard deviation of $\mathrm{V}$ for flat side transducers was higher than the values found for dry point transducers and jointly with the difficulties of coupling of transducers on the samples could have difficult the analysis of the results.

On the other hand, V obtained with dry point transducers showed a defined tendency, in which $\mathrm{V}$ decrease with an increase of the attack level. Treatments T1 and T2, that is no attack or low attack level, were significantly different in relation to treatment $\mathrm{T} 5$ (highest attack level for xylophagous organisms). Treatments T3 and T4 presented transitional characteristics in $\mathrm{V}$ and did not significant different in relation to the other treatments.

Other studies ${ }^{10,21}$ reported that the internal galleries created on wood by xylophagous organisms significant increase the empty spaces inside the material. The same authors affirmed that $\mathrm{V}$ is significantly affected by the attack level in the sample, that is, $\mathrm{V}$ decrease with an increase of attack level, which are related with decrease of D and weight of the material.

\subsection{Mechanical properties}

The mechanical properties of MOE and MOR gradually decreased with an increase of attack by xylophagous organisms on the wood. This behavior is related to the
Table 2. Statistical summary of the variation in basic density of Araucaria angultifolia wood attacked by xylophagous organisms classified according to attack level.

\begin{tabular}{ccccc}
\hline Group & $\begin{array}{c}\text { Mean } \\
\left(\mathbf{k g ~ m}^{-3}\right)\end{array}$ & Maximum & Minimum & $\begin{array}{c}\text { CV } \\
(\%)\end{array}$ \\
\hline T1 & $603.84 \mathrm{c}$ & 652.81 & 573.99 & 4.22 \\
T2 & $512.36 \mathrm{~b}$ & 564.63 & 427.81 & 7.05 \\
T3 & $508.09 \mathrm{~b}$ & 577.60 & 417.26 & 10.46 \\
T4 & $476.36 \mathrm{a}$ & 580.57 & 377.6 & 11.77 \\
T5 & $488.06 \mathrm{ab}$ & 552.57 & 384.03 & 10.37 \\
\hline
\end{tabular}

In which: $\mathrm{CV}=\mathrm{Coefficient}$ of variation $(\%)$. Means followed by the same letter in the column are not statistically different at $5 \%$ of the probability of error (Fisher LSD test).

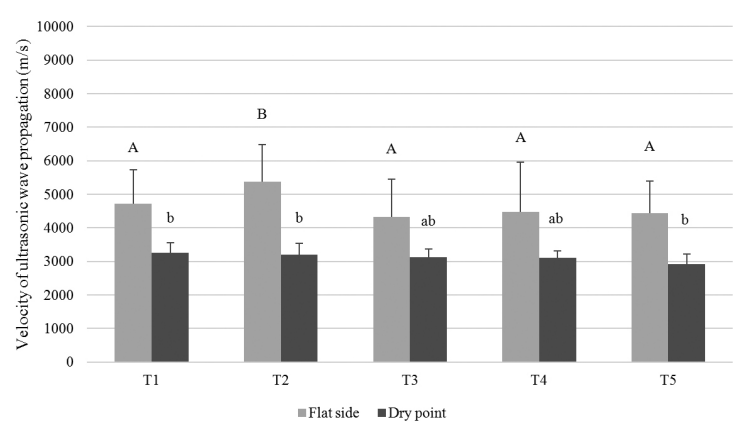

Figure 2. Mean values of $\mathrm{V}$ according to the attack level by xylophagous organisms. Means followed by the same letter, lowercase and uppercase, are not statistically different at $5 \%$ of the probability of error (Fisher LSD test).

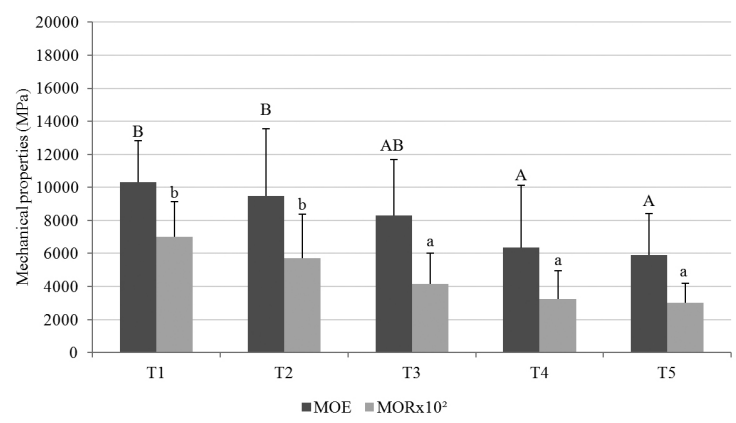

Figure 3. Mean values of MOR and MOE according to the attack level by xylophagous organisms. Means followed by the same letter, lowercase and uppercase, are not statistically different at $5 \%$ of the probability of error (Fisher LSD test).

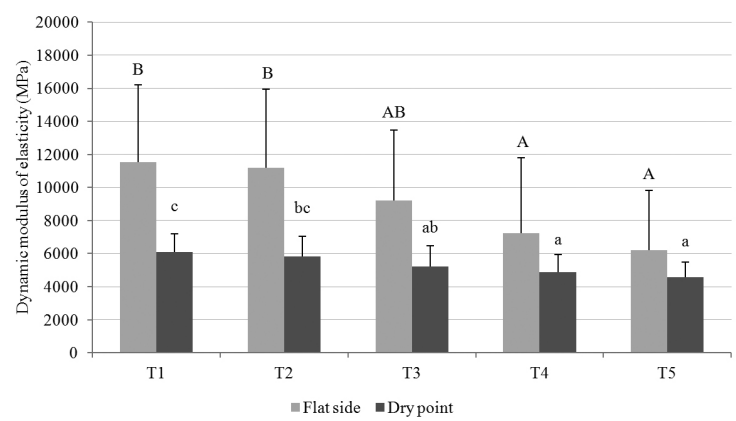

Figure 4. Mean values of $E_{D}$ (flat side and dry point transducers) according to the attack level by xylophagous organisms. Means followed by the same letter, lowercase and uppercase, are not statistically different at $5 \%$ of the probability of error (Fisher LSD test). 

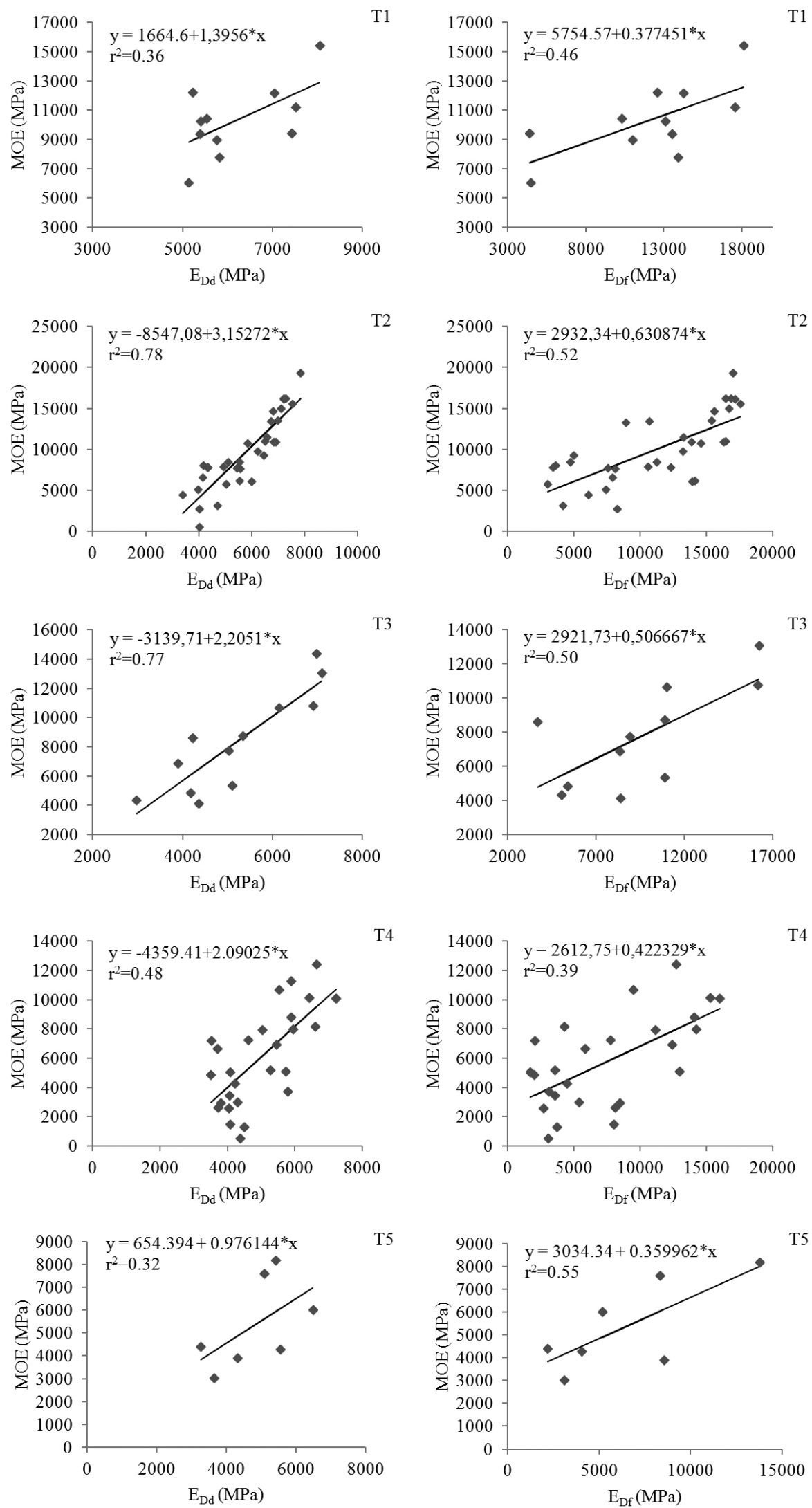

Figure 5. Linear regression models. Points $=$ observed data; Line $=$ Calculated data; $y=$ MOE - modulus of elasticity; $x=E_{D d}$ dynamic modulus of elasticity (dry point transducer) and $\mathrm{E}_{\mathrm{Df}-}$ dynamic modulus of elasticity (flat side transducer); $\mathrm{r}^{2}=$ coefficient of determination. 
deterioration caused by termites that form galleries inside the wood, compromise the physical structure and consequently the mechanical properties. This decrease of MOE and MOR is observed in Figure 3, which show the mean values of these properties in relation to the level of attack by xylophagous organisms.

The average values obtained for the samples without pathology (T1) are higher than those found in other study ${ }^{18}$, that reported average value of $9764 \mathrm{MPa}$ for MOE and 64 MPa for MOR. On the other hand, a research ${ }^{21}$ reported average value of $10841 \mathrm{MPa}$ for MOE and 74.6 MPa for MOR, which the first was similar and the last was higher than found in the present study $\mathrm{T} 1$. In other research ${ }^{19}$ with the same species, the authors found $11115 \mathrm{MPa}$ for MOE, which also was higher than T1 group of the present study.

Significant reduction in mechanical properties of wood from Eucalyptus urophylla, Melia azedarach, Lophantera lactescens, Pinus elliottii and Inga marginata species exposed to field tests were reported due to the action of biotic factors ${ }^{22}$. MOE decrease 1-38\% and MOR 5-52\% in wood samples of M. azedarach and E. urophylla, repectively. In the present study, reduction of MOE was 8.1, 19.7, 38.6 and $42.8 \%$ and reduction of MOR was 18.4, 40.6, 53.5 and $56.9 \%$ for $\mathrm{T} 2, \mathrm{~T} 3, \mathrm{~T} 4$ and $\mathrm{T} 5$, respectively, when compared to $\mathrm{T} 1$.

$\mathrm{E}_{\mathrm{Df}}$ (Fflat side transducers) and $\mathrm{E}_{\mathrm{Dd}}$ (dry point transducers) obtained similar values for MOE and MOR, in which these properties decrease with an increase of level of superficial attack (Figure 4). Researchers ${ }^{20}$ observed in a similar study that $\mathrm{E}_{\mathrm{D}}$ proportionally decreased with an increase of levels of attack by xylophagous organisms at the same way of variation found for $\mathrm{D}$.

T3 group was characterized as a transition group according to computerized analysis and Fisher's Test because $\mathrm{T} 1$ and T2 was statistically different at $5 \%$ of probability of error in relation to $\mathrm{T} 4$ and $\mathrm{T} 5$.

\section{References}

1. Dünisch O, Richter H and Koch G. Wood properties of juvenile and mature heartwood in Robinia pseudoacacia L. Wood Science and Technology. 2010; 44(2):301-313. http://dx.doi. org/10.1007/s00226-009-0275-0

2. Niemz P and Mannes D. Non-destructive testing of wood and wood-based materials. Journal of Cultural Heritage. 2012; 13(3):S26-S34. http://dx.doi.org/10.1016/j. culher.2012.04.001

3. Erikson RG, Gorman TM, Green DW and Graham D. Mechanical grading of lumber sawn from small-diameter lodgepole pine, ponderosa pine and grand fir trees from northern Idaho. Forest Products Journal. 2000; 50(7-8):59-65.

4. Ross RJ, Brashaw BK and Pellerin RF. Nondestructive evaluation of wood. Forest Products Journal. 1998; 48(1):1419.

5. Lee S, Lee S, Lee JS, Kim K, Lee J and Yeo H. Basic study on nondestructive evaluation of artificial deterioration of a wooden rafter by ultrasonic measurement. Journal of Wood Science. 2011; 57(5):387-394. http://dx.doi.org/10.1007/ s10086-011-1186-x

\subsection{Linear regression models}

Linear regression models (Figure 5) adjusted for independent variable $\mathrm{E}_{\mathrm{Dd}}$ showed higher significance than adjustments for $\mathrm{E}_{\mathrm{Df}}$, except in group $\mathrm{T} 1$. This behavior could be related to the resizing of the samples used in the tests with dry point transducers, in which the evaluation of internal defects of wood are better measured by ultrasound.

All the final models showed normality of data (ShapiroWilk test: p-value $>0.05$ ), variance heterogeneity (ShapiroWilk test: p-value $>0.05$ ) and independence of residuals (Durbin-Watson test: $\mathrm{p}$-value $>0.05$ ).

The results found in this study $\left(\mathrm{r}^{2}\right.$ between 0.32 and 0.78$)$ are similar to other models between $\mathrm{MOE}$ and $\mathrm{E}_{\mathrm{D}}$ reported in other studies. The use of ultrasound for determination of MOR is not recommended because the ultrasonic technique is based on Hooke's Law, which affirmed that the deformation is equal to the normal stress in elastic regime of any material and, consequently, differ of plastic regime (deformation is not proportional to the increase of normal stress $)^{23}$.

\section{Conclusions}

The nondestructive method of computerized visual analysis was accurate in the subdivision of surface attack levels. The ultrasonic method was efficient in the estimation of dynamic modulus of elasticity when used jointly to the computerized visual method.

Basic density, modulus of elasticity, modulus of rupture and dynamic modulus of elasticity proportionally decreased with an increase of attack level of xylophagous organisms, which confirmed accuracy of the method.

Use of dry point transducers showed the best linear regression models between static and dynamic modulus of elasticity than flat side transducers.

6. Oliveira FGR and Sales A. Relationship between density and ultrasonic velocity in Brazilian tropical woods. Bioresource Technology. 2006; 97(18):2443-2446. PMid:16311030. http:// dx.doi.org/10.1016/j.biortech.2005.04.050

7. MacHek L, Militz H and Sierra-Alvarez R. The use of an acoustic technique to assess wood decay in laboratory soil-bed tests. Wood Science and Technology. 2001; 34(6):467-472. http://dx.doi.org/10.1007/s002260000070

8. Oliveira FGR, Candian M, Lucchette FF, Salgon JL and Sales A. Moisture content effect on ultrasonic velocity in Goupia glabra. Materials Research. 2005; 8(1):11-14. http://dx.doi. org/10.1590/S1516-14392005000100004

9. Shiino MY, Faria MCM, Botelho EC and Oliveira PC. Assessment of cumulative damage by using ultrasonic C-Scan on carbon fiber/epoxy composites under thermal cycling. Materials Research. 2012; 15(4):495-499. http://dx.doi. org/10.1590/S1516-14392012005000062

10. Bucur V. Acoustics of Wood. 2nd ed. Nova York: SpringerVerlag; 2006.

11. Ross RJ and Pellerin RF. Nondestructive testing for assessing wood members in structures. Madison: Forest Products Laboratory; 1994. 
12. Pellerin RF and Ross JR. Nondestructive evaluation of wood. Madison: Forest Products Society; 2002.

13. Gonçalez JC, Valle AT and Costa AF. Estimativas das constantes elásticas da madeira por meio de ondas ultra-sonoras (ultra-som). Cerne. 2001; 7(2):81-92.

14. Brashaw BK, Bucur V, Divos F, Gonçalves R, Lu J, Meder $\mathrm{R}$ et al. Nondestructive testing and evaluation of wood: A worldwide research update. Forest Products Journal. 2009; 59(3):7-14.

15. Coradin VTR and Muniz GIB. Normas e procedimentos em estudos de anatomia da madeira: I - Angiospermae II - Gimnospermae. Brasil; 1992.

16. Associação Brasileira de Normas Técnicas - ABNT. NBR 7190 : Projeto de estruturas de madeira. Rio de Janeiro: ABNT; 1997.

17. American Society for Testing and Materials - ASTM. ASTM D 143-94: Standard methods of testing small clear specimens of timber. Annual Book of ASTM. West Conshohocken: ASTM; 2000.

18. Santini EJ, Haselein CR and Gatto DA. Análise comparativa das propriedades físicas e mecânicas da madeira de três coníferas de florestas plantadas. Ciência Florestal. 2000; 10(1):85-93.
19. Stangerlin DM, Domingues JMX, Santini EJ, Calegari L, Melo RR, Gatto DA et al. Obtenção do modulo de elasticidade em madeiras de Patagonula americana e Araucaria angustifolia por meio do método ultra-sonoro. Revista Científica Eletrônica de Engenharia Florestal. 2008; 11(1):1-15.

20. Reinprecht L and Hibký M. The type and degree of decay in spruce wood analyzed by the ultrasonic method in three anatomical directions. Bioresouces. 2011; 6(4):4953-4968.

21. Beltrame R, Souza JT, Machado WG, Vivian MA, Buligon EA, Pauleski DT et al. Propriedades físico-mecânicas da madeira de Araucaria angustifolia (Bertol.) Kuntze em três extratos fitossociológicos. Ciência da Madeira. 2010; 1(2):54-69. http:// dx.doi.org/10.12953/2177-6830.v01n02a05

22. Trevisan H, Tieppo FMM, Carvalho AG and Lelis RCC. Avaliação de propriedades físicas e mecânicas da madeira de cinco espécies florestais em função da deterioração em dois ambientes. Revista Árvore. 2007; 31(1):93-101. http://dx.doi. org/10.1590/S0100-67622007000100011

23. Alonso M and Finn EJ. Física: Um curso universitário, volume 1 - Mecânica. São Paulo; 1972. PMid:4112602. 